Sacrilegens, ISSN: 2237-6151 (Juiz de Fora, Minas Gerais, Brasil), vol. 16, núm. 2, 2019, pp. 204-231.

\title{
Da prece como poder mágico- religioso entre Eliade e Mauss à oração como poder escatológico-existencial entre Bultmann e Tillich.
}

Mariano da Rosa, Luiz Carlos.

Cita:

Mariano da Rosa, Luiz Carlos (2019). Da prece como poder mágicoreligioso entre Eliade e Mauss à oração como poder escatológicoexistencial entre Bultmann e Tillich. Sacrilegens, ISSN: 2237-6151 (Juiz de Fora, Minas Gerais, Brasil), 16 (2), 204-231.

Dirección estable: https://www.aacademica.org/marianodarosa.luizcarlos/105 ARK: https://n2t.net/ark:/13683/prnO/r8k

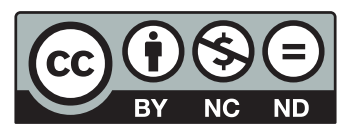




\title{
Da Prece Como Poder Mágico-Religioso Entre Eliade E Mauss À Oração Como Poder Escatológico-Existencial Entre Bultmann E Tillich
}

\author{
About Prayer As A Magic-Religious Power Between Eliade And Mauss \\ To Prayer As A Eschatological-Existential Power Between Bultmann \\ And Tillich
}

Luiz Carlos Mariano Da Rosa

Resumo: Sublinhando que a evocação dos acontecimentos que tiveram lugar $a b$ origine converge, segundo a perspectiva mítico-religiosa, para a manifestação das forças sagradas, de acordo com o referencial teórico-conceitual de Eliade, o artigo assinala que tal invocação implica uma correlação de narrativas míticas e gestos e ações paradigmáticas que se destinam a suscitar o poder sagrado e a produção de seus efeitos, ressaltando a prece como poder mágico de exercer influência sobrenatural, como afirma Mauss. Dessa forma, analisando a oração que caracteriza o monoteísmo judaico-cristão, o artigo assinala o relacionamento pactualque encerra Javé e Israel como um processo que implica a Sua invocação como Deus, que converge para manifestações e intervenções na vida do povo em sua realidade concreta, perfazendo, segundo a perspectiva bíblico-teológica neotestamentária, uma construção que encerra a expressão da existência escatológica e realização de si em Bultmann. Finalizando, baseado na perspectiva teológico-filosófica de Tillich, o texto sublinha o poder que implica a oração em um processo que se sobrepõe às estruturas supraindividuais de destruição através do novo ser que o Deus-Homem Jesus Cristo manifesta e que envolve a capacidade de superar as estruturas escravizadoras do mal e as consequências autodestruidoras do estado de alienação existencial.

Palavras-chave: Oração; Eliade; Mauss; Bultmann; Tillich.

Abstract: Underlining that the evocation of the events that took place ab origine converges, from the mythical-religious perspective, to the manifestation of the sacred forces, according to Eliade's theoretical-conceptual framework, the article points out that such invocation implies a correlation of mythical narratives. And paradigmatic gestures and actions designed to elicit sacred power and the production of its effects, highlighting prayer as a magical power to exert supernatural influence, as Mauss states. Thus, analyzing the prayer that characterizes Judeo-Christian monotheism, the article marks Israel's covenant relationship before Yahweh as a process that implies His invocation as God, which converges to manifestations and interventions in the life of the people in their concrete reality, making, according to the New Testament biblical-theological perspective, a construction that encloses Bultmann's expression of eschatological existence and self-realization. Finally, based on Tillich's theological-philosophical perspective, the text underscores the power that prayer implies in a process that overlaps the supraindividual structures of destruction through the new being that the God-Man Jesus Christ manifests and involves the

${ }^{1}$ Especialista em Ciências da Religião pela UCAM, em Filosofia pela UGF, Bacharel em Filosofia. 


\section{SACRILEGENS Revista Discente do Programa de}

ability to overcome the enslaving structures of evil and the self-destructive consequences of the state of existential alienation..

Keywords: Prayer; Eliade; Mauss; Bultmann; Tillich

\section{Introdução}

Caracterizando-se como uma mensagem cujo conteúdo envolve pedido insistente, rogo ou súplica, a prece implica uma manifestação de forte entusiasmo e grande intensidade de emoções em um movimento que tende ao ápice do envolvimento do ser humano em sua individualidade concreta e subjetividade empírica em sua totalidade com o Transcendente, convergindo para as fronteiras que assinalam a instauração de uma relação que guarda capacidade de exercer um determinado tipo de influência sobre o Ser Supremo no sentido de incliná-lo a agir em consonância com a sua vontade e desejo através de uma construção antropomórfica que apresenta o Divino como suscetível de persuasão e passível de afeto, a despeito do poder que detém como tal em um processo que encerra uma raiz de possibilidade que se mantém oculta sob a égide da soberania e dialoga com o Absoluto.

Encerrando comocondição fundamental a publicidade e a festividade no desenvolvimento de suas atividades cerimoniais, a religião, no sentido lato, implica o protótipo de um rito ou celebração que traz a oração como um de seus principais exercícios, juntamente com o sacrifício, a súplica e a ação de graças, através de uma construção que implica a reunião de crentes para a realização dos referidos atos sagrados em um processo que guarda correspondência com a adoração do Divino por intermédio de coisas e divindades e converge para a manutenção da lei e da ordem moral em uma sociedade tradicional ou primitiva.

Dessa forma, o artigo sublinha que a evocação dos acontecimentos e eventos que tiveram lugar $a b$ origine converge, segundo a perspectiva mítico-religiosa, para as fronteiras que encerram a manifestação das forças sagradas que, in principio, implicaram a Criação do Mundo, segundo o referencial teórico-conceitual de Eliade, que assinala que tal invocação possibilita a participação na plenitude primordial, em um movimento baseado na correlação de recitações e narrativas míticas e gestos e ações paradigmáticas que se destinam a suscitar a emergência do poder sagrado e a produção de seus efeitos correspondentes para a existência individual e coletiva. Assim sendo, o texto ressalta a prece como poder mágico de exercer influência 


\section{SACRII EGENS Revista Discente do Programa de}

sobrenatural por meio de palavras, como afirma Mauss (1979), que enfatiza que a eficácia que caracteriza a prece consiste na possibilidade de exercer uma influência que guarda capacidade de alcançar os recônditos da consciência.

Analisando os três tipos de oração que caracterizam o monoteísmo judaicocristão segundo a perspectiva bíblico-teológica veterotestamentária, a saber, petição, penitência e ação de graças, o artigo assinala que tal construção religiosa no relacionamento pactualque encerra Javé e Israelimplica um processo que geralmente envolve a Sua invocação como Deus e a exaltação dos aspectos que distinguem Jeová como tal e a exposição de um conteúdo peticionalque converge para manifestações e intervenções na vida do povo em sua concreticidade histórico-cultural, econômicosocial e político-jurídica.

Nesta perspectiva, sobrepondo-se às repetições das práticas mágico-religiosas do politeísmo ou paganismo, que guarda correspondência com recitações míticas e fórmulas mecânicas que se restringem à condição de técnicas verbais e métodos linguísticos que guardam capacidade de pretensão acerca do retorno à origem e à restauração de todas as coisas, o artigo assinala que a oração, segundo a perspectiva bíblico-teológica neotestamentária, implica uma construção de caráter permanente que independe da contingência das circunstâncias e das condições objetivas da realidade, convergindo para as fronteiras que encerram um movimento de expressão da existência escatológica em Bultmann entre a contingência e a transcendência que traz a emergência da criatividade diretiva de Deus em Tillich.

Dessa forma, baseado na perspectiva teológico-filosófica de Tillich, o texto se detém na relação envolvendo o sagrado e o não-sagrado em uma construção que mostra que a oração emerge como superação do estado de alienação existencial, na medida em que sublinha a mediação como um processo que, se de acordo com o paganismo, confere aos deuses mediadores a possibilidade de sua transformação em deuses por direito próprio ou por si mesmos, consiste, conforme a leitura do Judaísmo, em um movimento que encerra o próprio Deus que, no Lógos em Sua Encarnação, Morte e Ressurreição, se sobrepõe ao abismo incomensurável que institui a ruptura envolvendo o infinito e o finito, o incondicional e o condicionado. Assim sendo, o texto assinala que, convergindo para a mediação, a oração implica um poder que se sobrepõe às estruturas supraindividuais de destruição, na medida em que o novo ser que o Deus-Homem Jesus Cristo manifesta em sua existência histórico-cultural encerra a capacidade de superar as estruturas escravizadoras do 
mal e as consequências autodestruidoras do estado de alienação existencial que caracteriza o ser humano em sua individualidade concreta.

\section{Da invocação das forças sagradas e a participação na plenitude primordial em Eliade e a prece como poder mágico de exercer influência sobrenatural por meio de palavras em Mauss segundo a perspectiva mítico-religiosa}

Encerrando um movimento que implica uma repetição ininterrupta dos atos primordiais, os comportamentos e as práticas dos membros de uma comunidade arcaica ou sujeitos de uma sociedade tradicional guardam correspondência com as condutas e gestos paradigmáticos em uma construção que remete ao tempo sagrado, à condição originária da existência e aos Entes Sobrenaturais que inauguraram o mundo, institucionalizando modus essendi e modus operandi em relação ao mundo enquanto totalidade finita. Tal processo demanda a reatualização e rememoração como princípio de realidade, haja vista que a correspondência da ação concernente ao modelo exemplar lhe confere significado e valor em uma construção que, dessa forma, estabelece a sua participação em uma realidade transcendental, tornando o ser humano e a coletividade contemporâneos das personagens que viveram e atuaram in illo tempore, como também dos eventos que ocorreram ab origine.

Orientando os homens em suas relações entre si na esfera da comunidade e diante da natureza e do mundo, as "histórias" primordiais instituem valores e regras, práticas e condutas que se impõem como fundamento do seu modus vivendi no Cosmo, convergindo para um processo que encerra a necessidade envolvendo a incessante rememoração e a periódica reatualização do conteúdo mítico por intermédio de cerimônias e ritos que encerram as ocorrências e os eventos que se manifestaram ab origine e implicam a evocação do poder das coisas em sua condição originária.

\footnotetext{
"Viver" os mitos implica, pois uma experiência verdadeiramente "religiosa", pois ela se distingue da experiência ordinária da vida quotidiana. A "religiosidade" dessa experiência deve-se ao fato de que, ao reatualizar os eventos fabulosos, exaltantes, significativos, assiste-se novamente às obras criadoras dos Entes Sobrenaturais; deixa-se de existir no mundo de todos os dias e penetra-se num mundo transfigurado, auroral, impregnado da presenca dos Entes Sobrenaturais. Não se trata de uma comemoração dos eventos míticos mas de sua reiteração. $\mathrm{O}$ indivíduo evoca a presença dos personagens dos mitos e torna-se contemporâneo deles. Isso implica igualmente que ele deixa de viver no tempo cronológico, passando a viver no Tempo primordial, no Tempo em que o evento teve lugar pela primeira vez. (ELIADE, 1972, p. 22, grifos do autor)
} 
Possibilitando a sua transposição para o tempo sagrado por intermédio da evocação dos acontecimentos e eventos que encerram a condição originária da existência em sua totalidade envolvendo seres, coisas ou objetos, práticas e condutas, a narrativa mítica atribui ao sujeito e à coletividade o caráter de contemporâneo da Criação do Mundo, tanto quanto dos Deuses, Ancestrais Míticos e Heróis que in illo tempore presidiram o "começo" de tudo em um movimento que envolve a invocação das forças sagradas e a participação na plenitude primordial.

A manifestação das forças sagradas que, in principio, implicaram a Criação do Mundo, eis o que se impõe à evocação dos acontecimentos e eventos que tiveram lugar $a b$ origine em uma construção que encerra os seres, coisas ou objetos, práticas e condutas em sua condição originária e guarda capacidade de produzir a restauração de todas as coisas e a renovação da vida em um movimento que instaura um novo começo através de um processo que assinala a integração do sujeito ao instante intemporal e a reatualização do tempo mítico da "origem", convergindo para as fronteiras que envolvem a repetição do gesto paradigmático por meio da cerimônia mágico-religiosa de "retorno à origem".

Sobrepondo-se à noção que envolve a possibilidade de reparação da vida, na acepção da palavra, as comunidades arcaicas e sociedades tradicionais encerram uma psicologia e uma consciência que escapam às fronteiras que envolvem a recuperação da sua força e energia, ou o seu conserto ou aprimoramento ou remediação, o que implica a necessidade de sua recriação, uma nova criação propriamente, convergindo para um processo que encerra o "retorno à origem" como condição para a manifestação das forças que, in illo tempore, emergiram para a criação de todas as coisas ou objetos, seres, práticas e condutas, a Criação do Mundo, enfim. Dessa forma, o "retorno à origem" guarda a finalidade da comunicação da energia em sua plenitude no instante primordial da instauração da existência por intermédio de um movimento baseado na correlação de recitações e narrativas míticas e gestos e ações paradigmáticas que se destinam a suscitar a emergência do poder sagrado e a produção de seus efeitos correspondentes para a existência individual e coletiva em suas carências e necessidades concretas.

A prece é precisamenteum deles, o rito está aí unido à crença. Ela é cheia de sentidocomo um mito; ela é frequentemente tão rica em ideias e em imagensquanto uma narrativa religiosa. Ela é cheia de forca e de eficácia como um rito; ela é com frequência tão poderosamente criadora quanto umacerimônia simpática. Ao menos no principio, quando é inventada, elanão tem nada de cega; jamais possui algo de inativo. Assim, um ritualde preces é um todo, onde estão dados os elementos míticos e rituaisnecessários para compreendê-lo. (MAUSS, 1979, p. 104)

Sacrilegens, Juiz de Fora, v. 16, n. 2, p. 204-231, jul-dez/2019 


\section{SACRILEGENS Revista Discente do Programa de}

Atribuindo ao princípio da reciprocidade a estruturação da vida social em uma construção que converge para as fronteiras que encerram a lógica que envolve a coletividade e os processos que a caracterizam enquanto tal, Mauss (1979) assinala a possibilidade de afetação que se impõe à Divindade como condição que guarda correspondência com a correlação que há entre os seres humanos e a Divindade em um movimento que implica a participação de ambos no mesmo universo como um locus comum, constituindo-se um recurso que possibilita o exercício da ação sobre o mundo.

Sobrepondo-se ao caráter individual, a oração (prece), segundo Mauss (1979), consiste em um fenômeno que implica a coletividade, convergindo para as fronteiras que encerram um processo que impõe à Divindade a necessidade premente concernente à resposta, na medida em que envolve uma espécie de exortação neste sentido através da imputação de uma obrigação em uma construção categórica que pressupõe um estado originário de existência compartilhado por ambos, Divindade e ser humano.

Poder mágico de exercer influência sobrenatural por meio de palavras, eis o significado da prece, de acordo com Mauss (1979), que impõe as suas construções a condição de obscuridade própria do arcabouço mítico em um processo que escapa à absoluta compreensão, convergindo para um movimento que, funcionando como uma espécie de encantamento, encerra a capacidade de produzir uma iluminação súbita, pressupondo o exercício de uma força criadora que guarda raízes em um mundo transcendente e consiste em um fenômeno sobrenatural.

Nesta perspectiva, o que se impõe é a singularidade que caracteriza a oração como um fenômeno religioso que guarda correspondência com o contexto sóciohistórico-cultural, convergindo para uma manifestação cuja experiência encerra a sua delimitação, sobrepondo-se ao caráter de um acontecimento que escapa ao arcabouço espaço-temporal e as suas determinações em um processo que supostamente mantém independência absoluta em relação aos condicionamentos concretos da existência humana.

É para os ritos deste tipo que reservamos o nome de religiosos.Distinguem-se dos ritos mágicos por terem uma característica a mais: são eficazes, com eficácia própria ao rito, mas o são por eles mesmose por intermédio dos seres religiosos aos quais se dirigem. Assim, oindiano faz um rito mágico quando, partindo para a caça, se crê capazde parar o sol colocando uma pedra a uma certa altura da árvore, eJosué fazia um rito religioso quando, para parar o mesmo sol, invocava o todopoderoso Iavé. (MAUSS, 1979, p. 141) 


\title{
SACRII EGENS Revista Discente do Programa de
}

Se a eficácia que caracteriza a prece consiste na possibilidade de exercer uma influência que guarda capacidade de alcançar os recônditos da consciência em uma relação que envolve a sua totalidade, o que implica uma profundidade que encerra âmago e essência, a sua distinção sob a acepção de um processo que supostamente emerge como sagrado, concernente à magia ou ao encantamento mágico, que se circunscreve a um movimento mecânico, constitui-se, em suma, na condição dos ritos religiosos, cujo poder se impõe por si mesmos e por meio dos seres aos quais as suas práticas são direcionadas.

\section{Petição, penitência e ação de graças como tipos de oração no relacionamento pactualdo monoteísmo judaico-cristão segundo a perspectiva bíblico-teológicaveterotestamentária}

\begin{abstract}
Cura de doenças, libertação de um perigo mortal, castigo dos inimigos, o fim decalamidades nacionais - eis o que se impõe como conteúdo da oração, segundo a práticaisraelita, em um processo que converge para as fronteiras que encerram a vida em suaplenitude histórica e abrange saúde, boa velhice, prosperidade, descendência numerosa,progresso da nação e adoração a Javé, o que implica benefícios temporais que guardamcorrespondência com a necessidade de assegurar a verdadeira religião em uma construçãoque atribui à vida enquanto tal a condição de um precioso dom de Javé concedidoaos seus fiéis como membros da nação israelita e partícipes da sua aliança. (MARIANO DA ROSA, 2018, p. 62)
\end{abstract}

À oração, segundo a perspectiva do contexto histórico-cultural que caracteriza o mundo do Antigo Testamento, o que se impõe é a obediência, que encerra um caráter "dialogal" em um movimento que implica a correspondência do ser humano em sua concreticidade à vontade de Deus, convergindo para uma construção religiosa que atribui a condição de pecado à conduta incapaz de se sujeitar à determinação da palavra de Javé e da sua orientação, na medida em que, segundo a leitura hebraica, traz como significado "escutar", "responder", "fazer" o que foi mandado, tendo em vista que, em suma, o objeto da obediência não é senão o próprio Jeová.

Contrapondo-se ao processo que caracteriza o homo religiosus em sua relação com a Divindade no politeísmo e no paganismo em geral, a oração do povo de Israel tem como fundamento o relacionamento pactual²instaurado através da aliança instituída por Javé com Abraão em uma construção que envolve a sua descendência

${ }^{2}$ Instaurado através da experiência religiosa de Abraão, que transcende a economia do sagrado e os gestos arquetípicos que perfazem a relação da humanidade com a Divindade em sua acepção de deus otiosus e impõe "a diferença que existe entre a tradicional concepção da repetição de um gesto arquetípico e a nova dimensão, a fé, adquirida por meio da experiência religiosa" (ELIADE, 1992, p. 109 , grifo do autor). 


\section{SACRILEGENS Revista Discente do Programa de}

(física e espiritual) 3 e converge para as fronteiras que encerram um liame moral e ético 4 , que se sobrepõe às práticas mágico-religiosas 5 em vigor no referido contexto histórico-cultural e que, desde os primórdios, determinam a conduta religiosa que, baseada em um arcabouço de princípios e valores condensados em fórmulas e recitações, pressupõe a possibilidade de controle ou direção das ações divinas em benefício humano.

Visões de mundo não mágicas, personalistas, levam a uma relaçãode pessoa a pessoa com o poder divino, que é apropriado através daoração, isto é, através de um apelo ao centro pessoal do ser divino. Odeus responde em uma decisão livre: pode ou não usar seu poder para satisfazer o conteúdo da oração. (TILLICH, 2005, p. 221)

Sobrepondo-se à perspectiva antropológica que encerra dicotomia e dualidade, a oração que emerge do contexto histórico-cultural do Antigo Testamento guarda correspondência com bens de caráter temporal em uma construção que implica necessidades que convergem para as fronteiras que envolvem uma concepção antropológica baseada na unidade e na totalidade do ser em um processo que transpõe à distinção entre interioridade e exterioridade, subjetividade e objetividade, tornando conteúdo e objeto das orações as carências de ordem material ou histórica,

3 "Abraão foi o antecessor do Messias (Mt 1.1) e pai dos israelitas segundo a carne (Mt 3,9; Jo 8.33; At 13.26). Mas ele se tornou o pai espiritual de todos aqueles que compartilham a sua fé pelo Espírito Santo (Rm 4,11-16; 9.7; G1 3.16,29; 4,22,31). A fé de Abraão levou ao seu perdão, e tipifica o modelo de fé que devemos exercitar (Rm 4.3-11). As demonstrações de sua fé, ao obedecer à ordem de Deus para abandonar a Mesopotâmia, assim como o oferecimento de seu filho, Isaque, são mencionadoscomo exemplos notáveis de sua fé em ação (Hb 11.8-19; Tg 2.21)." (PFEIFFER; VOS; REA, 2007, p. 13)

4Tendo em vista que "as formulações do Seu concerto evidenciavam que Ele não estava preocupado com o rito de culto ou as celebraçoes orgíacas. Ao invés disso, Ele exigia um grau de obediência que permitisse que Abraão e seus descendentes andassem em Sua presença e vivessem vidas inocentes do ponto de vista moral e espiritual (Gn 17.1).” (VINE; UNGER; WHITE JR., 2002, p. 95)

5 Nesta perspectiva, convém esclarecer que magia é uma palavra que "vem do grego $\mu \alpha \gamma \varepsilon i \alpha$ (Sab 17,7), que significava originariamente a atividade ou a arte do mago, depois também a arte ou a atividade ocultas do feiticeiro, geralmente em sentido pejorativo. Por magia (feitico) entendemos ideias e práticas que se baseiam na crença de que certas pessoas, objetos ou ritos seriam capazes de causar um efeito anormal, fatal, infalível, através de determinados meios que não estão em nenhuma proporção com o fim desejado. Característico da magia é que esses magos, aplicando meios poderosos por eles mesmos inventados, se sentem independentes da soberania divina e da lei moral" (DICIONÁRIO, 2014, p. 923). O caso de Balaão(Nm22,23,24), contratado pelo reimoabitaBalaque para amaldicoar Israel, ilustra tal prática, adotada através de determinadas instituições, ritos e concepções pelo povo de Israel (Mq 5,10-15; Jr 27,9; Ez 13,18-21; Ml 3,5), conduta esta proibida pela lei mosaica: "A magia é completamente alheia ao javismo, conforme o qual é Deus quem, na natureza e no homem, cria, governa e domina tudo de acordo com a sua própria vontade, diante do qual o homem é pó e cinza (Gên 18,27), e do qual ele depende inteiramente (Núm 16,22; 27,16; Is 42,5; Jó 23,14s; Sl 104,29s). De fato, os israelitas conheciam a diferenca entre o que era operado pelos magos e o que vinha de Deus (cf. Êx 7,8-12; 7,15-22; 8,5-7; 8,16-19); por isso ações como as de Moisés (Ex 7,8-13; 15,22-25; 17,5s), Josué $(8,18)$, Elias (IR s 17,17-24; 18,42; 2 Rs 2,8) e Eliseu (2,19-22; 4,18-37; 4,38-42) não devem ser consideradas como magia, embora lhe sejam muito semelhantes. Enquanto o javismo não pôde assimilar as práticas mágicas, essas foram proibidas severissimamente pela lei mosaica ( $\hat{\mathrm{E}}$ x 22,17; cf. Lev 20,27; Dt 18,9-13; cf. ISam 28,3)" (DICIONÁRIO, 2014, p. 924). 
ou terrestre, tendo em vista que o conhecimento antropológico determinante produz tal construção na relação do israelita com Javé.

Buscar a face de Deus, eis o sentido de orar ou rezar, segundo a construção religiosa israelita que, baseada na aliança instituída entre Javé e os hebreus através do patriarca Abraão, implica o dever absoluto de uma relação que se sobrepõe aos "deuses" das nações, supostamente existentes, na medida em que o relacionamento pactual converge para assegurar a presença de Jeová no santuário de adoração do povo como fundamento do referido processo ${ }^{6}$, que traz como princípio a revelação tanto da sabedoria quanto do poder de Javé, assim como da justiça, fidelidade e bondade que o identificam como tal em um movimento que encerra as exigências morais expressas na Lei.

Constituindo-se um dos pilares do culto sinagogal, a oração em Israel torna-se um dever que impõe ao membro da comunidade a sua prática três vezes por dia, consistindo o altar, o santuário e o Templo de Jerusalém o locus primordial do processo, o qual, no entanto, se sobrepõe ao próprio ritual e ao contexto geográfico israelita, na medida em que a moradia serve também para tal fim em uma construção que assinala que a condição de ausência em relação ao locus primordial demanda uma postura exterior em direção ao templo de Jerusalém7.

Se "orar" ou "rezar" mantém correspondência com os verbos "ãtar e hitpallêl, de acordo com o Antigo Testamento, a oração litúrgica e a oração não-litúrgica, que

6 Dessa forma, torna-se relevante mencionar que a instituição da referida prática guarda correspondência com a inauguração do Templo de Jerusalém no exercício do governo do Rei Salomão durante a consagração da sede político-religiosa de Israel, em cuja cerimônia o líder máximo da nação apresentou a seguinte petição a Javé: "Atenta, pois, para a oração de teu servo e para a sua súplica, ó SENHOR, meu Deus, para ouvires o clamor e a oração que faz, hoje, o teu servo diante de ti. Para que os teus olhos estejam abertos noite e dia sobre esta casa, sobre este lugar, do qual disseste: $\mathrm{O}$ meu nome estará ali; para ouvires a oração que o teu servo fizer neste lugar. Ouve, pois, a súplica do teu servo e do teu povo Israel, quando orarem neste lugar; ouve no céu, lugar da tua habitaç̃o; ouve e perdoa" (BÍBLIA DE ESTUDO DE GENEBRA, I Rs 8,28-30, 1999, p. 403). Estabelecendo uma aliança com Davi, Javé escolhe Salomão para sucedê-lo como Rei de Israel, responsabilizando-o no sentido de construir o templo, assegurando apresença divina e a manifestação do seu poder no Templo de Jerusalém, conforme a petição ora apresentada a Jeová: "Sucedeu, pois, que, tendo acabado Salomão de edificar a Casa do SENHOR, e a casa do rei, e tudo o que tinha desejado e designara fazer, o SENHOR tornou a aparecer-lhe, como lhe tinha aparecido em Gibeão, e o SENHOR lhe disse: ouvi a tua oração e a tua súplica que fizeste perante mim; santifiquei a casa que edificaste, a fim de pôr ali o meu nome para sempre; os meus olhos e o meu coração estarão ali todos os dias" (BÍBLIA DE ESTUDO DE GENEBRA, I Rs 9,1-3, 1999, p. 405).

7Conforme exemplificação da conduta de Daniel diante do Rei Dario na corte do Reino da Babilônia depois da conquista do Império Medo-Persa em face da determinação real de instituir o decreto que proíbe a exposição de uma petição que não sejadirigida ao próprio monarca: "Daniel, pois, quando soube que a escritura estava assinada, entrou em sua casa e, em cima, no seu quarto, onde havia janelas abertas do lado de Jerusalém, três vezes por dia, se punha de joelhos, e orava, e dava graças, diante do seu Deus, como costumava fazer" (BIBBLIA DE ESTUDO DE GENEBRA, Dn 6,10, 1999, p. 993). 
implicam uma construção que envolve a expressão através da fala e por intermédio do cântico, encerram a possibilidade de guardar raízes no termo tefillah, cujo substantivo advém do verbo hitpallêl, consistindo em "perfume de sacrifício"8, por sua vez, o substantivo que se impõe através do verbo "ãtar, convergindo para um sentido que dialoga com o significado corporificado por termos tais como "desejar", "implorar clemência", "dizer" e "falar", "clamar", "chorar", "gemer"9, "suspirar" e "derramar sua alma diante de Deus".

${ }^{8}$ Estabelecendo correspondência envolvendo sacrifício e oração, a exposição de Levítico encerra a finalidade de possibilitar a instauração da relação entre Javé e os hebreus através de uma construção que consiste em um compêndio das leis divinas e implica a descrição de cinco tipos de ofertas, a saber, holocausto, oferta de manjares, oferta pacífica, oferta pelo pecado e oferta pela culpa, constituindo-se o holocausto('õlãh, em hebraico), cuja primeira ocorrência bíblica traz Noé edificando um altar e apresentando uma oferta a Deus (Gn 8.20), "a entrega total do coração e vida do oferecedor a Deus. As ofertas pelo pecado podiam acompanhar o holocausto quando o oferecedor estava especialmente preocupado com uma cobertura ou expiação de pecado (2 $\mathrm{Cr}$ 29.27). Quando as ofertas de paz acompanhavam os 'holocaustos' a preocupação do oferecedor enfocava a comunhão com Deus ( $2 \mathrm{Cr}$ 29.31-351. Antes da legislação mosaica, parece que o 'holocausto' servia à ampla gama de significados expressos em todos os vários sacrifícios mosaicos." (VINE; UNGER; WHITE JR., 2002, p. 203). Dessa forma, constituindo-se o holocausto uma oferta total cuja noção converge para a produção dos demais sacrifícios em suas especificidades, Houseexplica: "Cada tipo de oferta tem um propósito específico, mas, conforme observa Milgrom, 'o denominador comum é que surgem como resposta a uma imprevisível necessidade religiosa ou emocional e, desse modo, são colocadas à parte dos sacrifícios feitos por ocasiões de festas e jejuns públicos fixados no calendário (cap. 9, 16, 23; v. Nm 28 e 29)". Também têm em comum a seriedade do pecado e a alegria do perdão da culpa resultante do pecado. Cada oferta é de natureza substituinte e é também instrutiva para o ofertante.

Milgrom observa que a antigüidade do holocausto no mundo antigo indica que originalmente a oferta pode ter sido feita por motivos variados. Neste contexto, no entanto, a intenção é expiar o pecado. Mas expiar que tipo de pecado? O texto não diz. Pelo que parece, apresentar esse sacrifício é mais ou menos uma confissão geral de pecado, algo não muito diferente do 'perdoa as nossas dívidas' da oração dominical (v. Mt 6.9-13)." (HOUSE, 2005, p. 163)

Nesta perspectiva, cabe salientar que a correspondência envolvendo sacrifício e oração converge para as fronteiras que, em última instância, encerram um relacionamento pactual que encerra Javé e os hebreus que tende a sobrepor a oração ao sacrifício, na medida em que, a despeito de consistir em um "símbolo de reverência e louvor", "não substitui a obediência e a adesão fiel às exigências da aliança" (VANGEMEREN, 2011, p. 229), tendo em vista que "a noção absurda de que o Criador e soberano absoluto do universo requer sacrifícios de animais para comer é repudiada no Salmo 50. Nesse salmo, Javé, que demanda oração e ações de graça de seu povo em lugar de abundância de sacrifícios, faz a pergunta retórica: "Acaso, como eu carne de touros?" (besar 'abbirim, SI 50.13; cf. SI 140.6-8[7-9]; 51.15-17- [17-19]; Is 1.10-20; Jr 7.21-28; Am 5.21-27; Mq 6.6-8). Essa é uma rejeição da idéia primitiva e ingênua de sacrifício, de acordo com a qual os deuses participavam fisicamente das ofertas (Smith, 213-440; Davison, 257; Dummelow, 349; Kirkpatrick, 281; BratchereReybum, 462; cf. Dahood, 1966, 308 , que pensa que haja aí uma alusão à deusa carnívora Anate)." (VANGEMEREN,2011, p. 228-229). 9 Nesta perspectiva, cabe recorrer ao termo hebraico 'anãhâ, que guarda correspondência com o vocábulo "gemer" em uma construção que se sobrepõe à tradução que impõe o significado de "suspiro" ou "suspirar", que consiste em um processo que carrega uma intensidade menor quanto à audibilidade,convergindo para as fronteiras que encerram a manifestação de reações fortes (Ex 2.23) e a descrição de oracões angustiadas:"Associado a choro e aflição prolongada, o próprio gemido cansa o salmista (SI 6.6[7], cf. Jr45·3). É possível que a queixa dolorosa de Jó expresse a mesma idéia (Jó 23.2, considerando-se que o TM, 'minha mão pesa por causa de meu gemido', expressa exaustão e recusando-se a emenda por trás da LXX, Pex. e NIV). O esforço físico reduz o aflito a pele e osso (SI 102.5[6]) e, como em Jó 3.24, esse esforço está associado aos clamores altos (s'g, normalmente, o rugido de um leão) da oraço (SI 38.9[10]). Essas súplicas repletas de angústias e, por vezes, talvez inarticuladas, nascem de um coração desfalecido ( $\mathrm{Lm}$ 1.22) e expressam tormento profundo (SI 31.10[ 


\section{SACRII EGENS Revista Discente do Programa de}

La oración adquiere un significado decisivo. Se convierte en la súplica de un corazón puro, es decir, la realización personal mediante las cualidades de la santidad moral. Esta oración, al mismo tiempo es interpretada como el sacrificio perfecto, porque en ella se efectúa la dedicación de la voluntad. (TILLICH, 1973, p. 106)

Petição, penitência e ação de graças, eis os três tipos de oração que caracterizam a referida construção religiosa no relacionamento pactualque encerra Javé e Israel em um processo que geralmente envolve a Sua invocação como Deus e a exaltação dos aspectos que distinguem Jeová como tal e a exposição de um conteúdo peticionalque advém de uma necessidade ou desejo, convergindo para um retrospecto histórico concernente às Suas manifestações e intervenções na vida do povo em sua concreticidade histórico-cultural, econômico-social e político-jurídica em um movimento que tende a institucionalizar a noção de nação eleita pelo propósito do Altíssimo no sentido de revelar a Sua glória e majestade diante das nações do mundo e na terra em sua totalidade.

Dessa forma, guardando possibilidade de manter em sua estrutura o conteúdo que caracteriza a petição, a oração de penitência implica a exteriorização de uma sensação de incômodo ou transtorno, ou desordem, que guarda correspondência com um profundo sofrimento ou aflição que corporifica a condição de contrição ou arrependimento em uma construção que encerra a confissão de culpa e pecado e converge para um autoexame e uma autoavaliação que envolve motivações e intenções, valores e conduta, e demanda a disposição de mudança substancial de consciência e atitude em relação a Javé10.

A oração de ação de graças, por sua vez, carrega um conteúdo que denota gratidão e encerra a manifestação de reconhecimento da grandeza de Javé em uma

11 ]). A promessa de que os gemidos fugirão antevê o livramento divino da aflição produzida por essas orações (Is 35.10; 51.11).” (VANGEMEREN, 2011, p. 444)

${ }_{10}$ Conforme ilustra o Salmo 51, escrito por Davi quando o profeta Natã foi enviado por Javé para adverti-lo tanto acerca do relacionamento extraconjugal do rei com Bate-Seba, mulher de Urias, capitão do seu exército $(2 \mathrm{Sm} 11,1-5)$, como a respeito da sua responsabilidade envolvendo a morte de Urias no campo de batalha diante dos amonitas sob o comando do General.Joabe (2 Sm 11,6-13). Eis um paradigma de oração de penitência: "Compadece-te de mim, ó Deus, segundo a tua benignidade; e, segundo a multidão das tuas misericórdias, apaga as minhas transgressões. Lava-me completamente da minha iniquidade e purifica-me do meu pecado.Pois eu conheço as minhas transgressões, e o meu pecado está sempre diante de mim. Pequei contra ti, contra ti somente, e fiz o que é mau perante os teus olhos, de maneira que serás tido por justo no teu falar e puro no teu julgar. Eu nasci na iniquiidade, e em pecado me concebeu minha mãe. Eis que te comprazes na verdade no íntimo e no recôndito me fazes conhecer a sabedoria. Purifica-me com hissopo, e ficarei limpo; lava-me, e ficarei mais alvo que a neve. Faze-me ouvir júbilo e alegria, para que exultem os ossos que esmagaste. Esconde o rosto dos meus pecados e apaga todas as minhas iniqüidades. Cria em mim, ó Deus, um coração puro e renova dentro de mim um espírito inabalável."(BÍBLIA DE ESTUDO DE GENEBRA, Sl $51,1-10,1999$, p. 649) 


\section{SACRILEGENS Revista Discente do Programa de}

construção que exprime a condição de indignidade em relação à própria vida e existência, principalmente pelo fato da eleição divina e da atribuição a Israel como nação detentora da revelação do único e verdadeiro Deus, Jeová, que para esse fim planeja a sua formação e constituição em um processo que abrange desde o pacto instituído com o patriarca Abraão e a sua descendência até a libertação do povo israelita do Egito por intermédio da liderança de Moisés e o seu estabelecimento em Canaã através de Josué ${ }^{11}$.

Se a expressão de agradecimento consiste na demonstração verbal de uma condição subjetiva de certeza acerca da resposta divina, a confiança em Javé não elimina a necessidade de uma relação cuja intensidade emerge sob a acepção de um esforço "sistemático" que, caracterizando-se como um desafio ou situação que demanda uma disposição firme ou a superação das suas próprias limitações, converge para a construção de uma noção de Divindade que se sobrepõe à condição impessoal e abstrata a qual é relegada o divino e o sagrado segundo a perspectiva pagã ou politeísta que, em face da impossibilidade ou incapacidade de definir ou identificar Deus como Ser Pessoal, tende a diluir o conceito em uma multiplicidade que se reduz às fronteiras linguísticas em seu inelutável, infindo e inacabado movimento de apreensão do transcendente e da sua realidade ${ }^{12}$.

Convém salientar, no entanto, que, embora a oração do israelita tenha como objetivo a prosperidade individual e coletiva em função da condição do povo como detentor da revelação de Jeová - e, consequentemente, como instrumento da manifestação da sua sabedoria e poder diante das nações -, para além do ideal da maioria absoluta dos membros da comunidade israelita, as Escrituras registram experiências que se sobrepõem aos fatores determinantes do contexto histórico-

${ }_{11}$ "Guardando capacidade de atingir a condição absoluta de obediência, confiança e amor, o ato de Abraão, envolvendo a disposição de sacrificar o seu filho em holocausto a Deus em um movimento que alcança a situação-limite da imolação no altar, converge para mostrar para Deus a realidade de sua fé em um processo que se sobrepõe a um exercício intelectual ou emocional e converge para a instituição de uma aliança cuja garantia implica o juramento de Deus por Si mesmo e por Seu grande nome e que traz como conteúdo a promessa de transformação de sua posteridade em uma grande nação na medida em que a sua semente seria numerosa como as estrelas dos céus e a areia do mar em uma construção que encerra a posse da Palestina pela sua descendência, por intermédio da qual a bênção seria transmitida para todas as nações da terra, para o mundo inteiro." (ROSA, 2018, p. 173-174)

12 "O tipo mitológico de politeísmo não poderia viver sem restriç̃esmonoteístas. Uma destas restrições se manifesta no fato de o deus invocadoem uma situação concreta receber todas as características da ultimidade.No momento da oração, o deus a quem o ser humano ora é oúltimo, o senhor do céu e da terra. Isto é verdade apesar do fato de, naoração seguinte, outro deus assumir o mesmo papel. A possibilidade deexperimentar esse tipo de exclusividade denota que o ser humano vislumbraa identidade do divino, apesar da multiplicidade dos deuses e das diferenças entre eles." (TILLICH, 2005, p. 231) 
cultural e convergem para uma relação com Deus que somente é instaurada nas fronteiras neotestamentárias, o que implica, em suma, uma busca de Javé que transpõe qualquer tipo de carência ou necessidade histórica ou material em benefício da possibilidade de fruição de Deus pelo que em Si Ele é como doador último da vida e Supremo Bem ${ }^{13}$.

\section{Da oração como expressão da existência escatológica em Bultmann entre a contingência e a transcendência e a criatividade diretiva de Deus em Tillich segundo a perspectiva bíblico-teológica neotestamentária}

Se a concepção teológica do Antigo Testamento assinala um processo que, inter-relacionado ao contexto histórico-cultural, encerra a ação de Deus na concreticidade do mundo e do ser humano em um processo que converge para as fronteiras do antropomorfismo, a mediação implica, em seu sentido lato, a protagonização de seres sobre-humanos, ou seres cuja constituição correlaciona aspectos pessoais e impessoais, ou seres propriamente humanos, como reis, profetas, sacerdotes. Tal condição, no Antigo Testamento, é atribuída a Abraão, tanto quanto a Moisés, que estabelece a intermediação envolvendo Javé e os hebreus em uma construção que encerra a recepção do conteúdo teológico-doutrinário, ético-religioso, político-jurídico, econômico-social, exposto por Jeová em seu relacionamento pessoal com aquele que em seu nome, etimologicamente, carrega o sentido de "tirado das águas" ou "salvo das águas"14, por intermédio da liderança do qual Jeová liberta o seu povo do Egito e o encaminha para Canaã, a terra prometida.

${ }^{13}$ Tendo em vista que "em última análise, é um ultraje à santidade divina falar deDeus como falamos de objetos cuja existência ou não-existência possaser discutida. É um insulto à santidade divina tratar a Deus como umparceiro com quem colaboramos ou como um poder superior a queminfluenciamos mediante ritos e preces. A santidade de Deus toma impossívelsua insercão no contexto da correlação eu-mundo e sujeito-objeto.Ele mesmo é o fundamento e o sentido desta correlação, não umelemento dentro dela. A santidade de Deus exige que, em relação a ele,abandonemos a totalidade das relações finitas e entremos numa relaçãoque, no sentido categorial da palavra, não é, de modo algum, uma relacão." (TILLICH, 2005, p. 276)

14"Moisés é aquele que, nascido no Egito de pais israelitas, liberta os israelitas do Egito, promulga e escreve num livro as leis e prescricões de Javé, conduz os israelitas, através do deserto, para Canaã, sem ele mesmo entrar" (DICIONÁRIO, 2014, p. 1007). Guardando correspondência com mõseh(hebraico), conforme o nome do clã levítico müsi(Nm 26,58), Moisés é um nome tipicamente egípcio, "Ms" no lugar de Mosu (eliminando as vogais), implicando provavelmente msi, que significa "dar à luz": "Com este nome egípcio (cf. Amosis - Tutmosis), os hebreus vão jogar: Môsheh será aproximado de meshîtihu, eu o tirei, subentendido... das águas" (THIS, 1977, p. 57). 


\section{SACRILEGENS Revista Discente do Programa de}

Assumindo a intercessão15 dos seres humanos diante da Divindade, aos protagonistas da mediação cumpre a necessidade de instituir uma relação que se sobrepõe às condições ético-religiosas ou teórico-cognitivas ou psico-culturais dos membros de uma determinada coletividade diante do Ser Supremo em sua absoluta transcendência em um processo que implica a construção, se não da união, de uma aproximação gradual de um ser em sua absoluta finitude e um Ser em sua infinitude absoluta em um movimento que guarda possibilidade de ter como objeto e conteúdo peticional uma carência ou desejo cuja satisfação, absoluta ou relativa, emerge como sinal de favor divino e intervenção sobrenatural na vida do existente singular ou de uma comunidade na sua concreticidade histórico-cultural.

Se a instituição da aliança com a descendência física do patriarca Abraão no cativeiro egípcio tem Moisés como mediador em um processo que converge para a libertação dos hebreus e a constituição da nação israelita, por intermédio da qual advém o Messias prometido, o servo de Javé, predito pelo profeta Isaías ${ }^{16}$ e que em Jesus Cristo traz o seu cumprimento, funda através da Sua encarnação, morte e ressurreição um pacto que o torna mediador ${ }^{17}$ não apenas dos membros da comunidade israelita mas de todos os homens, independentemente da situação

15 Nesta perspectiva, convém esclarecer o sentido da intercessão na oração em uma construção que guarda correspondência com o sistema ético-religioso e a vida histórico-cultural do povo de Israel segundo o Antigo Testamento e em sua relação com a experiência existencial envolvendo o novo ser e o novo modo de existência instaurada na intervenção do Eterno no Temporal por intermédio da manifestação do Deus-Homem Jesus Cristo: "O pecado de Israel o separava de seu Deus (Is 59.2, hi.). De acordo com a maldição da aliança, Deus podia separar (bdl) o perverso para sofrer calamidade (Dt 29.21 [20], hi.). Por causa do pecado, Deus ordenou a Moisés e a Arão que se separassem do povo a fim de que o Senhor, em sua ira, consumisse Israel (Nm 16.21, ni.). A ameaça de separaç̃o permanente entre Deus e seu povo foi removida, nesse momento, pela oração intercessora de Moisés e Arão (Nm 16.22-24). Esse ato mostra a necessidade de um Intercessor perfeito maior que Moisés, capaz de remover, por meio de seu sacrifício expiatório, toda separação causada pelo pecado (Hb3; 9.11-10.18)." (VINE; UNGER; WHITE JR., 2002, p. 587)

${ }_{16}$ "Eis aqui o meu servo, a quem sustenho; o meu escolhido, em quem a minha alma se compraz; pus sobre ele o meu Espírito, e ele promulgará o direito para os gentios." (BÍBLIA DE ESTUDO DE GENEBRA, Is. 42.1, 1999, p. 834)

${ }_{17}$ "O que está no meio entre duas partes, com o fim de as reconciliar. A respeito da lei diz-se que 'foi promulgada por meio de anjos, pela mão de um mediador', Moisés (Gl 3.19); e Jesus é o 'Mediador de superior alianca', a 'nova alianç' (Hb 8.6; 9.15; 12.24), e 'um só Mediador entre Deus e os homens' (1 Tm 2.5)" (BUCKLAND, 1981, p. 282). Dessa forma, convém sublinhar, em relação à mediação de Cristo, que "está claro que em toda parte - especialmente em $\mathrm{Hb}$ - se abandona a opinião de que a graça de Deus pode e deve ser conseguida por meio de sacrifícios oferecidos por seres humanos, e - o que é inerente a isso - que a comunidade não necessita de pessoas de qualidades especiais, isto é, sacerdotes, para serem os mediadores entre elas e Deus. O sacrifício de Cristo tornou a graca de Deus eficiente de uma vez por todas, e ele é o sumo sacerdote da comunidade ( $\mathrm{Hb} 2.17 ; 3.1 ; 4.14 ; 5.1 \mathrm{ss}$; 7.1ss.; lClem $36.1 ; 61.3 ; 64$; InFld 9.1; PoIFil12.2). A própria comunidade é uma comunidade "santa",

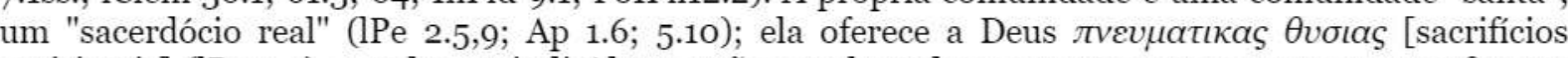

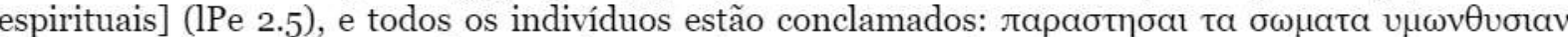

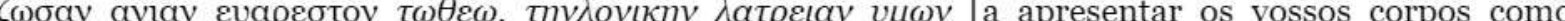
sacrifício vivo e santo a Deus, que é o vosso culto racional] (Rm 12.1). (BULTMANN, 2008, 163) 


\section{SACRII EGENS Revista Discente do Programa de}

espaço-temporal ou do contexto histórico-cultural ou ético-religioso ou econômicosocial, na medida em que o seu sacrifício expiatório, como Deus-Filho, Filho de Deus, Deus-Homem, possibilita a restauração absoluta do gênero humano à condição originária da criação em sua perfeição total.

Instaurando através da encarnação, morte e ressurreição uma experiência existencial que implica a emergência de um novo ser e de um novo modo de existência, Jesus Cristo, Deus-Homem, institui uma nova relação entre o ser humanoem sua individualidade concreta e subjetividade empírica e Deus, na medida em que corporifica uma fé capaz de exercer uma confiança absoluta no Pai Celestial em uma construção baseada na incomensurabilidade do amor de Deus, na inesgotabilidade da Sua misericórdia e na infalibilidade da Sua providência ${ }^{18}$.

Nesta perspectiva, instituindo uma nova experiência existencial entre o ser humano e Deus, Jesus Cristo, Deus-Homem, como "Lógos-encarnado-morto-eressuscitado" corporifica, por intermédio da oração, a unidade envolvendo finitude e infinitude que caracteriza a condição humana nas fronteiras que implicam a redenção humana em um processo que encerra a transposição da condição servil do formalismo religioso em seu cerimonialismo e ritualismo exterior para a condição filial e o seu movimento de interiorização e internalização de um conteúdo que mais do que valores, práticas e condutas implica o Absoluto e Transcendente, o "Ser-emSi”"19, que por meio do Espírito Santo torna o ser humano "habitat" divino.

Assumindo uma atitude de incessante oração, Jesus Cristo encerra em sua existência um perfeito relacionamento com Deus-Pai, na medida em que encarna uma conduta que assinala absoluta dependência, total obediência e completa sujeição ao Pai Celestial, conforme demonstra a Sua interação permanente com o Absoluto e Transcendente em um processo que converge para as fronteiras que, em suma,

18 "Para Jesus, Deus tornou-se novamente um Deus da proximidade. Ele é o poder presente, envolvendo, delimitando e desafiando a cada um como Senhor e Pai. Isso encontra sua expressão na forma como Jesus se dirige a Deus na oração. Em contraste com as fórmulas pomposas, patéticas, muitas vezes liturgicamente bonitas, muitas vezes também sobrecarregadas, com as quais o judaísmo costuma dirigir-se a Deus em oração - p. ex., na oração das 18 preces, que o judeu devoto tem que recitar três vezes por dia: 'Deus de Abraão, Deus de Isaque, Deus de Jacó! Deus supremo, fundador de céu e terra! Nosso escudo e escudo de nossos pais!" - Jesus dirige-se a Deus com o simples 'Pai!' como aliás, em geral, o 'pai-nosso' se distingue das orações judaicas por sua singela brevidade (Mt 6.913 ou Lc 11.2-4). Deus está próximo; ele ouve e compreende as preces que vêm a ele como o pai entende o pedido do filho (Mt 7.7-11 par.; cf. Lc 11.5-8; 18.1-5)." (BULTMANN, 2008, p. 62, grifos do autor)

19 "O ser de Deus é o ser-em-si. Nãose pode entender o ser de Deus como a existência de um ser ao lado deoutros ou acima de outros. Se Deus é um ser, ele está sujeito às categoriasda finitude, especialmente ao espaço e à substância. Mesmo quandoé chamado o 'ser supremo' no sentido de o 'mais perfeito' e o 'mais poderoso', a situação não muda." (TILLICH, 2005, p. 242) 


\title{
SACRILEGENS Revista Discente do Programa de
}

envolvem a vivência da vontade de Deus através da experiência existencial de comunicação com o Eterno que, no caso de Jesus Cristo, tem uma singularidade que corresponde à sua condição de Unigênito Filho de Deus.

\begin{abstract}
Contanto que o revelador [Jesus Cristo] proporciona aos crentes um relacionamento com Deus, este é o da oracão, no qual ambas as coisas encontram sua expressão: a certeza da ligação como da distância.A oração mostra novamente que o crente ainda se encontra $\varepsilon v \tau \omega \kappa o \sigma \mu o v$ [no mundo], mas, não obstante, é a

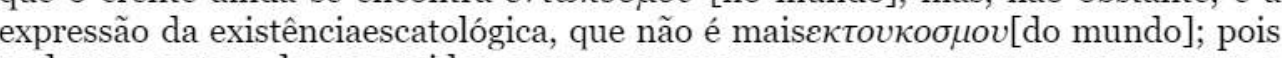

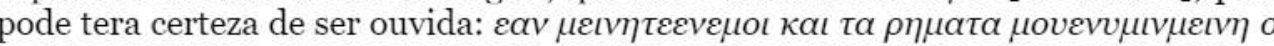

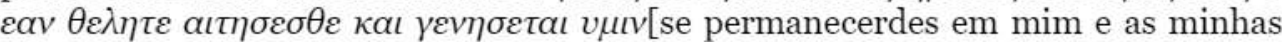
palavras permanecerem em vós, pedireis o quequiserdes e vos será feito] (15.7). pssa promessa é repetida em singularesvariações: ora é a oração dirigida ao Pai "em nome deJesus", que o Pai atenderá $(15.16 ; 16.24,26)$, que o Pai atenderá "em nome de Jesus" (16.23), ora é a oração "em nome de Jesus" que elepróprio atenderá (14.13s.). Todas as variacões expressam somente isto: essa oração somente e possível àquele para aquele o relacionamento com Deus foi aberto por Jesus e permanecerá aberto sempre. (BULTMANN, 2008, 524, grifos do autor)
\end{abstract}

Trazendo o sentido de invocação da Divindade, a oração, de acordo com a leitura neotestamentária, emerge de um termo específico, a saber, $\boldsymbol{\pi \rho о \delta \varepsilon v \chi о \mu \alpha , ~}$

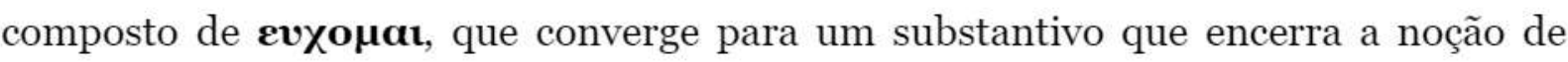
promessa ou voto em uma construção que implica também verbos que carregam o significado de "pedir", "abençoar", "dar graças", "adorar", "invocar" e "suplicar".

Sobrepondo-se às repetições sem sentido que caracterizam as práticas mágicoreligiosas do politeísmo ou paganismo, a oração, segundo o princípio instituído pelo Senhor Jesus, demanda uma disposição inabalável do agente no exercício da fé em um movimento irredutível à instabilidade e inconstância da dúvida, o que implica uma construção de caráter permanente que independe da contingência das circunstâncias e das condições objetivas da realidade em sua concreticidade histórico-cultural, convergindo para a sua afirmação como fundamento da relação envolvendo o ser humano em sua individualidade efetiva e subjetividade empírica e Deus, o Pai Celestial. Tal movimento encerra a necessidade de transcender a carga de motivos condensada no objetivo imediato do processo através de uma conduta orientada pela persistência e perseverança como capacidade de conservar o propósito, que não se esgota na concretização da aspiração, haja vista que, mais do que expor um pretexto para a manifestação do poder divino, a busca deve ter como fim, em última instância, o próprio Deus, Absoluto e Transcendente, como "Realidade-em-Si".

Consistindo em um processo que implica a possibilidade de encerrar a petição em função de carências e necessidades do ser humano em sua concreticidade histórico-cultural, a oração requer a consciência do sujeito a respeito da Onisciência 


\section{SACRILEGENS Revista Discente do Programa de}

de Deus em uma construção que escapa às fronteiras que encerram a exposição de informações e veiculação de dados objetivando a introdução de um conteúdo em condição fática ou virtual na esfera da cognição divina a fim de persuadir ou convencer a Divindade a cumprir a vontade do existente singular ${ }^{20}$, mas consiste em um relacionamento intersubjetivo que pressupõe uma postura interior correspondente, na medida em que traz como base conteudístico-formal um liame de ordem moral em um processo que implica humildade ${ }^{21} \mathrm{e}$ obediência ${ }^{22}$.

Estabelecendo a mediação entre o ser humano em sua individualidade concreta e subjetividade empírica e Deus, Jesus Cristo, Deus-Homem, confere aos seus discípulos autorização para o recurso ao Seu Nome como base conteudísticoformal da oração de petição em uma construção que institui a união em Si do Criador e da criatura, na medida em que através da Sua Encarnação, Morte e Ressurreição possibilita a instauração de um novo ser e de um novo modo de existência. Tal processo implica a inauguração de uma aliança que encerra a superação da ruptura abísmica entre o Divino e o Humano em virtude do estado de pecaminosidade imposto desde o acontecimento da queda adâmica, que demanda um sacrifício expiatório que em função da necessidade de purificar a consciência somente a Divindade cabe oferecer em uma construção que, para além das práticas litúrgicas e ritos ético-religiosos baseados em uma relação que se detém nas fronteiras da exteriorização cerimonialística, converge para a experiência existencial do perdão $a_{b s o l u t o} 23$ do Pai Celestial e da transformação da interioridade em sua totalidade.

${ }^{20 " A}$ criatividade diretiva de Deus responde à pergunta pelo sentido da oração, especialmente das orações de súplica e de intercessão. Nenhuma dessas orações pode significar que se espera que Deus interfira

nas condições existenciais. Ambas significam que se pede a Deus quedirija a situação dada à sua plenitude. As orações são um elemento nessasituação, e, se forem orações verdadeiras, são um fator muito poderoso nessa situacão." (TILLICH, 2005, p. 272)

${ }^{21}$ Conforme a exemplificacão relatada por Jesus Cristo em "A Parábola do Fariseu e do Publicano": "Propôs também esta parábola a alguns e que confiavam em si mesmos, por se considerarem justos, e desprezavam os outros: Dois homens subiram ao templo com o propósito de orar: um, fariseu, e o outro, publicano. O fariseu, posto em pé, orava de si para si mesmo, desta forma: O Deus, graças te dou porque não sou como os demais homens, roubadores,injustos e adúlteros, nem ainda como este publicano; jejuo duas vezes por semana e dou o dízimo de tudo quanto ganho. O publicano, estando em pé, longe, não ousava nem ainda levantar os olhos ao céu, mas batia no peito, dizendo: ó Deus, sê propício a mim, pecador! Digo-vos que estedesceu justificado para sua casa, e não aquele; porque todo oque se exalta será humilhado; mas o que se humilha será exaltado." (BÍBLIA DE ESTUDO DE GENEBRA, Lc 18,9-14, 1999, p. 1212)

${ }_{22}$ "Amados, se o coraç̃o não nos acusar, temos confiança diante de Deus; e aquilo que pedimos dele recebemos, porque guardamos os seus mandamentos e fazemos diante dele o que lhe é agradável. (BÍBLIA DE ESTUDO DE GENEBRA, I Jo 3,21-22, 1999, p. 1513)

${ }_{23}$ Tendo em vista que a oração consiste, em suma, na exposição humana de sua culpabilidade fundamental: "De início, quando, por mandado do Senhor, os santos repetem diariamente esta prece: 'Perdoa nossas dívidas' [Mt 6.12], sem dúvida estão confessando que são devedores. Nem pedem em 


\section{SACRILEGENS Revista Discente do Programa de}

La oración, sin embargo, no es primordialmente la súplica por un corazónlimpio, sino la del perdón de los pecados, es decir, la súplica por aquella forma de gracia que se da de manerainmediata en la relación teocrática con lo Incondicional. Bajo eldominio del concepto paradójico de "justificación por la fe" esta forma de la gracia se convierte en el centro de la doctrina paulina y protestante de la gracia. $\mathrm{Al}$ mismo tiempo, sin embargo, se intuyela presencia de Dios de manera sacramental en el símbolo concreto del mediador divino que se sacrifica por sí mismo; participar en esta autodedicación equivale a la redención y a la realizaciónpersonal. (TILLICH, 1973, p. 107-108)

Superando a condição de intermediário envolvendo Deus e o ser humano em sua individualidade concreta e subjetividade empírica em um processo que converge para as fronteiras que encerram a possibilidade de comunicação com a Divindade 24 , Jesus Cristo não se limita ao ensino da oração como exercício fundamental para a instauração de uma relação intersubjetiva com o Pai Celestial, mas atribui aos discípulos e a todos aqueles que se dispõem a crer Nele como Deus-Filho e Redentor a necessária autorização para usar o Seu Nome em uma construção verbal que implica a manifestação do poder do Lógos em Sua encarnação, morte e ressurreição.

Dessa forma, detendo o poder em sua plenitude, Jesus Cristo não apenas realiza obras que se sobrepõem às limitações da natureza em seu sentido lato e à finitude da condição humana, mas atribui aos seus discípulos uma capacidade de transcender às condições de existência histórico-cultural que traz a fé como fundamento ético-lógico, no sentido de confiança absoluta na Divindade como Pai Celestial em uma relação que envolve a união substancial entre o Pai, o Filho e o Espírito, e encerra a autorização acerca da utilização do Nome do Senhor como base conteudístico-formal da oração25.

vão, porque o Senhor, por toda parte, outra coisa não prescreveu que se deva buscar senão aquilo que ele mesmo houvesse de dar. Ainda mais, embora testificasse que toda oração haverá de ser ouvida pelo Pai, no entanto esta absolvição selou-a com promessa, além do mais, especial. Que mais queremos?" (CALVINO, 4, I, 23, 2006, p. 47).

${ }^{24}$ Dessa forma, cabe salientar que tal é a profundidade do relacionamento instaurado entre Deus-Filho e Deus-Pai que não é senão o termo aramaico $A b a$ registrado na literatura neotestamentária como base nominal da oração de Jesus, que invoca Deus-Pai desse modo, empregando a referida palavra aramaica, que significa Pai, como uma espécie de nome próprio. Aba consiste em um "termo familiar em aramaico usado pelos judeus. Cristo usou este termo na sua oração (Mc 14:36). É bem possível que ensinou aos discípulos a dirigirem-se a Deus da mesma forma (Lc 11:2); ainda que não fosse usado pelos judeus no seu culto" (A BÍBLIA VIDA NOVA, O NOVO TESTAMENTO DE NOSSO SENHOR JESUS CRISTO, 1995, p. 187, N.A.).

25 "E como nesta oracão o orante se confessa a Jesus por meio do 'em nome de Jesus",assim também se confessa a Jesus ao atender 'em nome de Jesus'. Assim é indiferente se pedimos a Deus ou a Jesus, se é Deus quem atende a oração ou Jesus. No entanto, a fim de manter afastada a concepção mitológica, na qual se imagina o Jesus exaltado como uma pessoa intercessora, que se encontra entre Deus e os seres

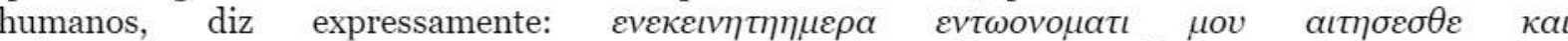

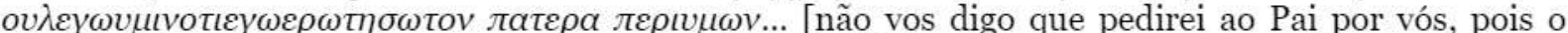
próprio Pai vos ama, porque vós me amastes...] (16.26s.)." (BULTMANN, 20o8, p. 524) 


\section{SACRII EGENS Revista Discente do Programa de}

Tornando Jesus Cristo intercessor diante de Deus de todos os seres humanos que em sua individualidade concreta e subjetividade empírica se sujeitam ao seu poder e se dispõem ao exercício da fé como uma prática que traz como conteúdo e fim o próprio Deus, o sacrifício voluntário do Deus-Homem através da crucificação configura o derramamento de sangue sem pecado em um movimento que converge para as fronteiras que encerram a redenção humana, e cuja aplicação acarreta resultados que transcendem o contexto histórico-cultural e as suas determinações. Dessa forma, além do Seu Nome como base conteudístico-formal da oração, Jesus Cristo, Filho de Deus, Deus-Homem, assegura o resultado do referido exercício que, uma vez tendo-o como destinatário e baseado na fé como fundamento ético-lógico, emerge como portador de um potencial ilimitado.

Se a prece característica das práticas litúrgico-rituais do politeísmo ou do paganismo guarda correspondência com recitações míticas e fórmulas mecânicas que se restringem à condição de técnicas verbais e métodos linguísticos que guardam capacidade de promover, em última instância, o retorno à origem e a restauração de todas as coisas, a oração neotestamentária implica o princípio da adoção²6, conforme modelo elaborado pelo Deus-Homem Jesus Cristo que, como "Lógos-encarnadomorto-e-ressuscitado", institui uma relação que traz como fundamento o amor incondicional do Pai Celestial no processo que transforma a criatura em um novo ser, convergindo para atribuir ao ente em sua antagônica disposição intelecto-afetiva, emocional, psicológica, consciencial, volitiva, ético-religiosa, etc., a filiação divina imbricada no exercício da fée ${ }^{27}$.

${ }^{26}$ Cabe sublinhar que a prática relacionada à adoção "no primeiro século era o meio pelo qual o pai adotivo escolhia um filho para perpetuar o seu nome e herdar a sua herança" (A BÍBLIA VIDA NOVA, O NOVO TESTAMENTO DE NOSSO SENHOR JESUS CRISTO, 1995, p. 187, N.A.), conforme expressão usada pelo Apóstolo Paulo na Epístola aos Romanos: "Porque não recebestes o espírito de escravidão, para viverdes, outra vez, atemorizados, mas recebestes o espírito de adoção, baseados no qual clamamos: Aba, Pai. O próprio Espírito testifica com o nosso espírito que somos filhos de Deus. (BÍBLIA DE ESTUDO DE GENEBRA, Rm, 8,15-16, 1999, p. 1330). Importa observar também a utilizaç̃o do termo na Epístola aos Gálatas: "E, porque vós sois filhos, enviou Deus ao nosso coracão o Espírito de seu Filho, que clama: Aba, Pai! De sorte que já não és escravo, porém filho; e, sendo filho, também herdeiro por Deus." (BÍBLIA DE ESTUDO DE GENEBRA, Gl 4,6-7, 1999, p. 1395)

${ }_{27}$ "Esta realidade é o Novo Ser, que vence a alienação existenciale, portanto, torna possível a fé. Só isso a fé é capaz de garantir - precisamente porque sua própria existência é idêntica à presença do Novo Ser. A própria fé é a evidência imediata (não mediada por conclusões)do Novo Ser dentro e sob as condições da existência." (TILLICH, 2005, p. 403) 


\title{
Da relação envolvendo o sagrado e o não-sagrado e a oração como superação do estado de alienação existencial em Tillich segundo a perspectiva teológico-filosófica
}

\begin{abstract}
O caráter inacessível de Deus ou a impossibilidade de estabelecer com ele uma relação no sentido próprio da palavra está expresso na palavra "santidade". Deus é essencialmente santo, e toda relação com ele supõe a consciência de que é paradoxal estar em relação com aquilo que é santo. Deus não pode se tomar um objeto de nosso conhecimento ou um parceiro de nossa ação. Se falamos, como certamente devemos fazê-lo, da relação eu-tu entre Deus e o ser humano, o tu abarca o eu e,conseqüentemente, a relação inteira. Se não fosse assim, se a relação eu-tu com Deus fosse mais própria do que simbólica, o eu poderia subtrair-se à relação. Mas não existe lugar no qual o ser humano possa fugir doeu divino, porque este inclui o eu e está mais perto do eu do que o eu desi mesmo. (TILLICH, 2005, p. 276)
\end{abstract}

A possibilidade de expressar o significado incondicional, eis o que caracteriza toda a realidade e toda a ação que guardam raízes nas fronteiras do sagrado, convergindo para um processo que correlaciona sagrado e não-sagrado na constituição da realidade cuja estrutura envolve tensões e rupturas em um movimento que contempla formas inovadoras de adaptação, acomodação e ajuste em uma construção que traz como condição fundamental a instabilidade e o atrito que emergem através do encontro ou entrecruzamento ou embate das forças antagônicas em sua articulação.

Caracterizada pelo símbolo que encerra "fundamento" e "abismo", a relação envolvendo o significado incondicional e o significado condicional consiste na condição sine qua non para a emergência do sagrado (ou do santo) em um processo que assinala que a realidade sagrada (Sein) encerra em si a afirmação e a negação do existente (Seiende).

Sobrepondo-se a realidade particular em sua totalidade em um movimento caracterizado pela transcendência absoluta, o significado incondicional emerge como fundamento da realidade existente em sua profundidade, convergindo para um processo que atribui ao finito a sua verdadeira natureza e significado em uma relação que implica a negação da aparência do real.

Circunscrevendo o seu caráter a capacidade de negar o existente em sua totalidade em um movimento que implica a própria negação de si, o objeto sagrado converge para as fronteiras que envolvem uma realidade que encerra o abismo absoluto do significado.

Lo Santo atraviesa la forma inmediata del existente; pose ecualidades extáticas. Toda realidad (Sein) santa es una realidade extática; es decir, una realidad que, 


\section{SACRIILGENS Revista Discente do Programa de}

reventando, atraviesa su forma dada de manera inmediata; posee una trascendencia interna que llega más allá de su carácter formal, de su ser dado como objeto de la cultura. Esto vale para la esfera subjetiva de todo acto de fe, sea que se lo exprese a través de la oración personal o en el transporte que disuelve la consciência del éxtasis místico. (TILLICH, 1973, p. 71)

Guardando caráter extático, o sagrado (ou santo) se impõe à forma do existente em sua imediaticidade em um movimento que envolve a transposição dos seus limites próprios, na medida em que detém uma transcendência interna que, encerrando em sua natureza a impossibilidade de conter-se enquanto tal, converge para uma manifestação que se mantém irredutível a sua expressão ordinária, segundo o paradigma lógico-racional.

Guardando correspondência com o processo que tende a relegar à condição de abstração o Deus Supremo em uma construção que converge para as fronteiras que o caracterizam como remoto, distante, inalcançável, a mediação implica um conceito que emerge tanto do âmbito do paganismo quanto da esfera do Judaísmo, encerrando o desejo do ser humano envolvendo a manifestação concreta do Divino em sua existência em um processo que, segundo a perspectiva do paganismo, confere aos deuses mediadores a possibilidade de sua transformação em deuses por direito próprio ou por si mesmos, enquanto que, de acordo com a leitura do Judaísmo, os mediadores se mantém sob a égide de Javé.

Sobrepondo-se ao abismo incomensurável que institui a ruptura envolvendo o infinito e o finito, o incondicional e o condicionado, a mediação, segundo a perspectiva do Cristianismo, encerra o significado de reunião, consistindo em uma função salvadora em um processo que atribui a ação que implica a salvação e a mediação a Deus, na medida em que Deus é o sujeito da mediação e da salvação por intermédio de uma construção que converge para as fronteiras que assinalam que "Ele [Deus]não necessita reconciliar-se com o ser humano, mas convida o ser humanoa se reconciliar com ele." (TILLICH, 2005, p. 385).

Tornando Deus presente diante do ser humano, Cristo revela em si o ser humano que corresponde à vontade de Deus em um processo que se sobrepõe à condição que encerra uma realidade distinta entre ambos, no sentido de uma terceira realidade, mas que implica a representação do "dever-ser" do ser humano em seu estado essencial nas fronteiras que envolvem a existência e as suas determinações.

Se a caracterização do mediador como uma realidade ontológica que se impõe entre Deus e o ser humano converge para as fronteiras que encerram uma cristologia de caráter falso, Cristo consiste no "homem essencial", que "representa a imagem 


\section{SACRILEGENS Revista Discente do Programa de}

original de Deus corporificadano ser humano, mas o faz sob as condições da alienação existenteentre Deus e o ser humano" (TILLICH, 2005,p. 385), em uma construção que se sobrepõe à condição de um ser que, simultaneamente, emergiria na qualidade de um semideus e de um semi-humano, o que o tornaria incapaz de representar Deus diante dos seres humanos, tanto quanto também oser humano diante dos seres humanos.

Tornar presente a humanidade essencial por intermédio de uma vida pessoal nas fronteiras do estado de alienação que caracteriza o ser humano em sua existência em relação a Deus, eis o que se impõe como paradoxo da mensagem cristã em uma construção que assinala que a união envolvendo Deus e o ser humano na natureza humana essencial consiste em uma determinação própria, típica, que encerra a dialética abrangendo o infinito e o finito.

Escapando à condição de um mito de transmutação e à noção que envolve uma transformação que converge para a emergência de uma terceira realidade na relação que encerra Deus e o ser humano, o processo que implica a "encarnação", baseado no acontecimento que guarda raízes na identificação expressa no "fazer-se" carne do Lógos, converge para a participação de Deus na condição humana em um movimento que mantém correspondência com a existência histórica e uma vida pessoal."Em tudo

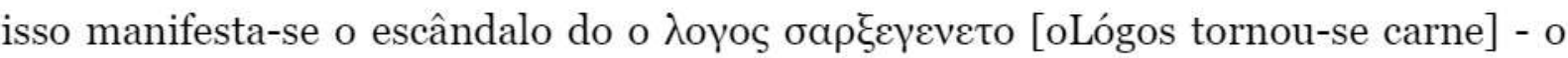
escândalo que consiste no fato de queo revelador aparece como ser humano que não deve demonstrarperante o mundo sua afirmação de ser o Filho de Deus." (BULTMANN, 2008, p. 477-478)

Dessa forma, sobrepondo-se à perspectiva politeísta e à noção "mitológica" que envolve a possibilidade de transmutação de seres divinos em objetos naturais ou seres humanos, a encarnação no sentido que implica o "fazer-se" carne do Lógos como o princípio que encerra a automanifestação divina, na medida em que o "Logos' éo princípio da automanifestação divina em Deus bem como no universo, na natureza bem como na história" (TILLICH, 2005, p. 386). Tal processo converge para um acontecimento que guarda raízes nas fronteiras da manifestação do "homem essencial" que, como "Filho de Deus", "Homem Espiritual" ou "Homem do Alto", participa da condição humana em seu estado de alienação existencial em uma experiência existencial que instaura a criação do sentido da história humana em uma construção que, em última instância, acena com a salvação dos seres humanos, a 


\section{SACRILEGENS Revista Discente do Programa de}

transformação da existência histórica do ser humano e a renovação do universo em sua plenitude:

O universorenascerá em um novo éon. A função do portador do Novo Ser não éapenas salvar indivíduos e transformar a existência histórica do ser humano,mas também renovar o universo. E o pressuposto em que se fundamentaessa visão é que a humanidade e os seres humanos individuaisdependem tanto dos poderes do universo que a salvação de um é impensável sem a salvação do outro. (TILLICH, 2005, p. 386-387)

Exercendo um poder que se sobrepõe às estruturas supraindividuais de destruição, o novo ser que o Deus-Homem Jesus Cristo manifesta em sua existência histórico-cultural supera as estruturas escravizadoras do mal e as consequências autodestruidoras do estado de alienação existencial que caracteriza o ser humano em sua individualidade concreta, consistindo os milagres do Filho de Deus em ocorrências que assinalam a sua plena participação na condição humana e a consequente identificação com o infortúnio da situação humana em um processo que implica uma "antecipação representativa" do predomínio do novo ser diante de uma série de desordens que abrangem doenças mentais e corporais, catástrofes e necessidades, desespero e morte.

Nesta perspectiva, se a fé caracteriza o novo serem uma construção mediante a qual o existente singular crê na criatividade diretiva de Deus, a oração implica um poder que se sobrepõe à intensidade do desejo que o seu conteúdo guarda capacidade de expressar, convergindo para as fronteiras que encerram a transformação da situação existencial em um processo que atribui a precedência ético-lógica do novo serem relação ao novo ato ou comportamento, haja vista que consiste na condição sine qua non para a instauração de uma nova conduta a superação do fato universal do estado de "escravidão da vontade" 28 .

Convergindo para as fronteiras que envolvem uma relação pessoal com o poder divino, o que implica a correspondência do ser humano enquanto existente singular ao chamado ou invocação do próprio Ser Divino, a oração encerra a tensão da correlação abrangendo imanência e transcendência em um processo que transpõe as estruturas da razão subjetiva e da razão objetiva através de um movimento que institui a união entre a criatura e o Criador, como o "Ser-em-Si", no sentido de fundo

28 "É a incapacidade do ser humano de quebrar sua alienação. Apesar do poder de sua liberdade finita, ele é incapaz de consumar a reunião com Deus. No âmbito das relações finitas, todas as decisões são expressões da liberdade finita do ser humano, mas elas não conseguem a reunião com Deus; permanecem no âmbito da 'justiça civil, das normas morais e legais.Mas inclusive essas decisões, apesar da ambigüidade de todas as estruturasda vida, estão relacionadas com o não-ambíguo e último.” (TILLICH, 2005, p. 371-372) 


\title{
SACRII EGENS Revista Discente do Programa de
}

criador:"Falar a Deus e receber uma resposta formam uma experiência extática emilagrosa; transcendem todas as estruturas comuns da razão subjetiva eobjetiva. Constituem a presença do mistério do ser e uma efetivação de nossa preocupação última” (TILLICH, 2005, p. 139). Tal experiência, que envolve mistério, milagre e êxtase, signos da revelação, consiste na ascensão do coraçãoem um movimento que implica a elevação do centro da personalidade a Deus e converge para uma resposta que guarda correspondência com uma decisão que emerge da Sua absoluta liberdade.

\section{Conclusão}

\begin{abstract}
Con la creciente personalización y trascendencia de lo Santo en las religiones culturales politeístas, las categorías personales y sociales del cultus obtienen predominancia. La unión con lo Santo se convierte en una relación personal con Dios, el sacrifício viene a ser la devoción personal, el éxtasis deviene um estado de ser imbuido del Dios concreto. Dios, como portador de las formas, esa hora el Señor y el Soberano, el cultus es "servicio divino" (Gottesdienst). La palabra extática se transforma en oración personal. Los antiguos sacrificios y ritos de purificación pierden su carácter sacramental inmediato y son, ahora, actos de devoción. En la pura teocracia pierden totalmente su significado. En su lugar hace aparición la realización de la forma pura: la obediencia es mejor que el sacrificio. El servicio divino es el establecimiento de la soberanía de Dios, el sacrificio es el renunciamiento de la propia voluntad. (TILLICH, 1973, p. 106)
\end{abstract}

A vida em sua plenitude, segundo o conhecimento antropológico determinante, eis o conteúdo e objeto da oração do israelita em sua relação com Javé, o que implica uma construção que, além de questões materiais ou históricas, ou terrestres, envolve aspirações que guardam correspondência com carências de ordem emocional, psicológica, atrelada ao exercício da religião como relacionamento pactual com Deus, que converge para um processo que atribui às condições necessárias para a sua experiência coletiva o objetivo da oração, que geralmente encerra como petição, em suma, a providência protetora de Jeová em face de riscos e perigos de desagregação ético-religiosa, político-jurídica, econômico-social, históricocultural, haja vista a condição da nação israelita como detentora da revelação concernente ao único Deus, criador e mantenedor do mundo e de todas as coisas e seres.

Se a oração, de modo geral, guarda correspondência com o contexto históricocultural, as exceções, registradas nas Escrituras, assinalam uma construção que tende às fronteiras que encerram uma relação intersubjetiva, cujo conteúdo e objeto, sobrepujando às carências ou necessidades de ordem histórica ou material, convergem para a interiorização do processo em um movimento que não mais se 


\section{SACRILEGENS Revista Discente do Programa de}

reduz às implicações da exterioridade do mundo histórico-cultural, mas que alcança uma dimensão existencial que demanda, afinal, a instauração de uma experiência capaz de produzir um novo ser e um novo modo de existir.

O cumprimento da oração não consiste no cumprimento de desejos mundanos

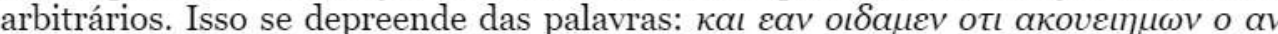

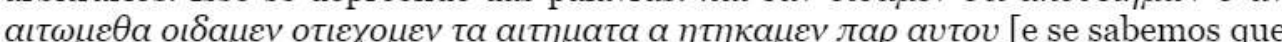
ele ouve o que nós lhe pedimos, sabemos que temos os pedidos que lhe fazemos] (1Jo 5.15),istoé, haja o que houver: é o atendimento da oração - ou melhor: aprópria oração já é o atendimento. Isso, porém, vale, e vale somente,quando, na oracão, a existência escatológica se torna, por meiodisso, consciente de que pede a Deus a realização de si mesma "em nome de Jesus". (BULTMANN, 2008, p. 524)

Independentemente do seu objeto, a oração implica um resultado que guarda correspondência com a fé imbricada em um processo que requer a certeza absoluta da realidade que emerge como conteúdo da esperança como uma experiência de apropriação subjetiva que se sobrepõe às condições objetivas da existência históricocultural e à contingência das circunstâncias, convergindo para uma disposição inabalável do sujeito no sentido de afirmar categoricamente e vivenciar efetivamente como um fato um fenômeno que até então permanece reduzido às fronteiras da possibilidade 29 .

Trazendo um conteúdo de caráter universal, a oração converge para as fronteiras que encerram a temporalidade da existência histórico-cultural e da contingência das circunstâncias e a atemporalidade da vida espiritual em sua transhistoricidade e trans-objetividade através de uma construção que correlaciona a aspiração do ser humano em sua individualidade concreta e subjetividade empírica e a vontade de Deus, que se sobrepõe aos desejos humanos até mesmo no movimento que implica a correspondência às suas necessidades30.

Constituindo-se como intercessor diante de Deus-Pai em favor dos seres humanos, Jesus Cristo cumpre a mediação absoluta que se impõe entre o Criador e a

${ }^{29}$ Tendo em vista que "a fé na criatividade diretiva de Deus constantementeé desafiada pela experiência de um mundo em que as condiçõesda situação humana parecem excluir tantos seres humanos de uma

plenificação até mesmo provisória e fragmentária. Morte prematura, condiçõessociais destrutivas, debilidade mental e insanidade, os horroresnunca atenuados da existência histórica - tudo isto parece confirmar afé na fatalidade, mas não a fé na providência. Como se pode justificarum Deus todopoderoso (theos-dike) em vista de realidades nas quaisnão se pode discernir o menor sentido?" (TILLICH, 2005, p. 274)

30"Por ser a expressão da existência escatológica, essa oração pode ter a certeza de ser ouvida. Pois quem, na fé, se tornou senhor sobre o mundo, também o é na oração; isto é, sua oração não mais está determinada pelo anseio e pela preocupação com o futuro mundano. Pois o atendimento é prometido para aquele que 'permanece em Jesus' e 'no qual permanecem as palavras de Jesus'(5.7). Desse modo a oração é designada expressamente como um $\alpha \iota \omega \mu \varepsilon \theta \alpha \kappa \alpha \tau \alpha \tau o \theta \varepsilon \lambda \eta \mu \alpha$ $\alpha v \tau o v$ [pedir de acordo com sua vontade] (1Jo 5.14)." (BULTMANN, 2008, p. 524) 


\section{SACRILEGENS Revista Discente do Programa de}

criatura em uma construção que envolve a encarnação, a morte e a ressurreição do Lógos, que converge para atribuir ao Nome do Filho de Deus a autoridade máxima no mundo em sua totalidade e no universo em sua plenitude, na medida em que consiste na base conteudístico-formal da oração, tanto quanto no destinatário pessoal do referido processo comunicacional, convergindo para uma união substancial que encerra Deus-Pai, Deus-Filho e Deus-Espírito em uma relação que transforma o existente singular em "habitat" da Divindade.

Caracterizando-se como um movimento que transcende a matriz lógico-racionalda existência espaço-temporal a oração consiste em um processo que correlaciona temore tremor na medida em que o pensamento torna-se incapaz de fundamentar, haja vistaque a contemplação do Transcendente no esgotamento da linguagem se sobrepõe aosentido do imanente e da finitude e tende ao êxtase que implica a união de todo o ser àDeus como Lógos em uma experiência que escapa à definição e à inteligibilidade eemerge como irredutível ao saber, guardando-se para além de métodos ou sistemas,conceitos ou juízos, em uma construção que se impõe como uma relação com o "Ser-em-Si" através de uma inexaurível imersão em sua realidade que se torna capaz de produzira progressiva desalienação humana. (MARIANO DA ROSA, 2018, p. 67, grifos do autor)

Nesta perspectiva, se o que se impõe é Deus como Uno Transcendente sob a acepção de um princípio absolutamente inefável em virtude da sua incognoscibilidade em uma construção que converge para as fronteiras da revelação enquanto automanifestação divina, a oração implica um movimento dialético envolvendointeriorização e exteriorização que alcança a sua máxima expressão em uma relação que se sobrepõe à comunicação verbal e aos códigos linguísticos ${ }^{31}$, encerrando uma construção irredutível ao sistema lógico-racional que abrange o ser humano em sua individualidade concreta e subjetividade empírica e a totalidade do seu ser32. Tal processo, que não se circunscreve às fronteiras da consciência33, converge para a imersão do eu enquanto manifestação absoluta do finito no Supremo Bem em um movimento que produz inelutavelmente uma experiência existencial que,

${ }_{31}$ "A oração pode movimentar-se entre os extremos de discurso consciente, de compreensão clara, e a emissão de sons inarticulados na glossolalia (lCo 14.14s.); pode ser um suspiro inarticulado (Rm 8.26) ou um clamor extático de $A b b a$ (Rm 8.15; GI 4.6)." (BULTMANN, 2008, p. 215)

32 "A revelação é a manifestação do mistério do ser para a funçãocognitiva da razão humana. Ela medeia um conhecimento. Tal conhecimento,no entanto, só pode ser recebido em uma situação revelatória,

através do êxtase e do milagre. Esta correlação indica o caráter especial do 'conhecimento da revelação'. Como o conhecimento da revelaçãonão pode ser separado da situação de revelação, não podemos introduzi-lono contexto do conhecimento comum como um acréscimo, independentementeda maneira peculiar como foi obtido e recebido." (TILLICH, 2005, p. 140-141)

33 "En virtud del hecho que lo Santo trasciende de manera tanto positiva como negativa todas las formas inmediatas de la consciencia, se convierte para la consciencia, por un lado en la realización hacia la cual ésta tiende y por otro en el abismo ante el cual se retrocede; y los dos están unidos. Lo primero convierte a lo Santo en una bendición para el hombre, es decir, en aquello dentro de lo cual la conciencia encuentra su realización incondicional; lo segundo convierte a lo Santo en el Inviolable, al que la consciencia secular jamás debiera acercarse." (TILLICH, 1973, p. 73) 
nas fronteiras do "Lógos-encarnado-morto-e-ressuscitado" como "Filho de Deus", "Homem Espiritual" ou "Homem do Alto",tende, para além do Ser, ao êxtase34 do amor como presença total.

\section{Referências bibliográficas}

A BÍBLIA VIDA NOVA. Tradução de João Ferreira de Almeida. Edição revista e atualizada no Brasil(Editor: Russell P. Shedd). São Paulo / Brasília: Vida Nova / Sociedade Bíblica do Brasil, 1995.

BÍBLIA DE ESTUDO DE GENEBRA. Tradução de João Ferreira de Almeida. Revista e Atualizada. São Paulo / Barueri: Cultura Cristã / Sociedade Bíblica do Brasil, 1999.

BUCKLAND, A. R. Dicionário bíblico universal (Com o auxílio do Rev. Dr. Lukyn Williams). Tradução de Joaquim dos Santos Figueiredo. São Paulo: Editora Vida, 1981.

BULTMANN, Rudolf. Teologia do Novo Testamento. Tradução de Ilson Kayser. Santo André: Editora Academia Cristã, 2008.

CALVINO, João. As Institutas da Religião Cristã (Volume 4). Tradução deWaldyr Carvalho Luz. São Paulo: Cultura Cristã, 2006.

DICIONÁRIO Enciclopédico da Bíblia. São Paulo: Paulus Editora, 2014.

ELIADE, Mircea. Mito do eterno retorno. Tradução de José A. Ceschin. São Paulo:

Mercuryo, 1992.

ELIADE, Mircea. Mito e realidade. Tradução de Pola Civelli. São Paulo: Perspectiva, 1972.

HOUSE, Paul R. Teologia do Antigo Testamento. Tradução de Sueli Silva Saraiva. São Paulo: Editora Vida, 2005.

LUCCIONI, Gennie; et al. Atualidade do mito. Tradução de Carlos Arthur R. do Nascimento.São Paulo: Duas Cidades, 1977.

MARIANO DA ROSA, Luiz Carlos. A oração entre as práticas mágico-religiosas do politeísmo e orelacionamento pactual do monoteísmo: da superação do determinismo da história em Mircea Eliade à presença do mistério do ser em Paul Tillich, Revista Teológica DOXIA (Fabra/Puc-Rio), Serra/ES, v. 3 n. 3. p. 4675, jan./jun. 2018.

34"O êxtase não é uma negação da razão; é um estadomental em que a razão está além de si mesma, isto é, além da estruturasujeito-objeto. Ao estar além de si mesma, a razão não nega a si mesma. A 'razão extática' continua sendo razão; ela não recebe nada irracionalou anti-racional - o que não poderia fazer sem autodestruir-se - , mastranscende a condição básica da racionalidade finita, a estrutura sujeito-objeto.

Este é o estado que os místicos procuram alcançar mediante suasatividades ascéticas e meditativas. Mas os místicos sabem que estas atividadessão apenas preparatórias e que a experiência do êxtase se deveexclusivamente à manifestação do mistério em uma situação revelatória.O êxtase só ocorre se a mente se sentir possuída pelo mistério, isto é,pelo fundamento do ser e do sentido." (TILLICH, 2005, p. 124-125) 
MAUSS, Marcel. A Prece. In: Roberto Cardoso de Oliveira (Org.). Marcel Mauss:Antropologia. Tradução de Regina Lúcia de Moraes Morel. São Paulo: Ática, 1979(Coleção Grandes Cientistas Sociais).

PFEIFFER, Charles F.; VOS, Howard F.; REA, John. Dicionário bíblico Wycliffe.Tradução de Degmar Ribas Júnior. 2. ed. Rio de Janeiro: CPAD, 2007.

ROSA, Luiz Carlos Mariano da.Abraão e a fé prototípica: da fé como paradoxo absoluto à fécomo encarnação do absoluto no Deus-Homem Jesus Cristo. PLURA, Revista de Estudos de Religião (ABHR), ISSN:2179-0019, Juiz de Fora/MG, v. 9, n. 2, 2018, p. 162-184.

THIS, Bernard. Incesto, adultério, escrita. In: LUCCIONI, Gennie; et al. Atualidade do mito. Trad. de Carlos Arthur R. do Nascimento. São Paulo: Duas Cidades, 1977, p. 41-74.

TILLICH, Paul.Filosofia de lareligion.Traducción: Marcelo Pérez Rivas. Buenos Aires: EdicionesMegápolis / Asociación Editorial La Aurora, 1973.

TILlICH, Paul. Teologia sistemática. Tradução Getúlio Bertelli e Geraldo Korndörfer. São Leopoldo: Sinodal, 2005.

VANGEMEREN, Willem A. Novo dicionário internacional de teologia e exegese do Antigo Testamento. Volume 1. Tradução de Equipe de colaboradores da Editora Cultura Cristã. São Paulo: Cultura Cristã, 2011.

VINE, W. E.; UNGER, Merril F.; WHITE JR., William. Dicionário Vine. O significado exegético e expositivo das palavras do Antigo e do Novo Testamento. Tradução de Luís Aron de Macedo. Rio de Janeiro: CPAD, 2002. 